\title{
Craintilleux (Loire)
}

\section{La Ronze}

\section{Éric Thévenin}

\section{(2) OpenEdition}

Édition électronique

URL : http://journals.openedition.org/adlfi/6899

ISSN : 2114-0502

Éditeur

Ministère de la culture

Référence électronique

Éric Thévenin, «Craintilleux (Loire) », ADLFI. Archéologie de la France - Informations [En ligne], RhôneAlpes, mis en ligne le 01 mars 2007, consulté le 02 mai 2019. URL : http://journals.openedition.org/ adlfi/6899

Ce document a été généré automatiquement le 2 mai 2019.

(c) Ministère de la Culture et de la Communication, CNRS 


\title{
Craintilleux (Loire)
}

\author{
La Ronze
}

\section{Éric Thévenin}

Identifiant de l'opération archéologique : 229503

Date de l'opération : 2007 (EX)

1 Le projet de création d'une carrière de granulats de très grande ampleur ( $44 \mathrm{ha}$ ) justifiait l'intérêt porté à cette première phase de diagnostic. Au total, le projet d'exploitation comptera six opérations d'interventions préventives échelonnées sur plusieurs années.

2 Une première phase a porté sur une emprise de $77000 \mathrm{~m}^{2}$. Elle se situe au sud de la commune de Craintilleux (Loire) et occupe au lieu-dit la Ronze (en rive gauche de la Loire), le centre de la plaine alluviale du Forez.

3 Tous les sondages se sont avérés négatifs (absence totale d'indice même pour les périodes historiques) et n'ont donc pas permis d'apporter d'informations concrètes concernant l'occupation de cette zone géographique. La stratigraphie se limitait à des dépôts stériles de nature marneuse, postérieurs aux alluvions anciennes du premier palier de la plaine du Forez.

4 THÉVENIN Éric

\section{INDEX}

Index géographique : Rhône-Alpes, Loire, Craintilleux operation expertise (EX) 
AUTEURS

ÉRIC THÉVENIN 